\title{
HOLOCENE LAKE AND SHALLOW WATER SEDIMENTS AT MOGRAT ISLAND, SUDAN
}

\author{
Annett Dittrich ${ }^{1}$, Sayantani Neogi ${ }^{2}$ \\ ${ }^{1}$ Hausburgstr. 24, 10249 Berlin, Germany; e-mail: a.dittrich@archaeologie-agentur.de \\ ${ }^{2}$ University of Cambridge, United Kingdom; e-mail: sn370@cam.ac.uk
}

\begin{abstract}
This paper presents the results of stratigraphic excavation and soil studies carried out at Mograt Island, the largest of the Nilotic islands in Sudan. Due to its restricted insular environments, Holocene alluvial deposits were observed to be interlocked with archaeological remains of different periods, allowing for a combined chronostratigraphic approach to study both cultural and climatic events. To better understand the environmental context through soil components and pedological features at a microscopic scale, soil block samples were accordingly collected and studied by the application of soil micromorphology. This approach provides insights into the history of Nile terrace aggradation through the suspension of Nile sediment loads under stillwater conditions as well as of the periodical establishment of shallow water pools at the islands' plateaus by the surface run-off from local rains. Since these patterns vary significantly from the present situation, they offer a key to the scenario in which specific early agricultural and animal herding practices evolved.
\end{abstract}

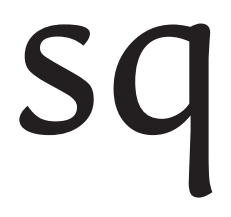

Key words: Holocene, Nile Valley, insular environments, palaeolakes, soil micromorphology

Manuscript received 18 October 2016, accepted 12 April 2017

\section{INTRODUCTION}

Mograt Island is located at the first great Nile bend between the Fifth and the Fourth Nile Cataract (Fig. 1). With a length of $31 \mathrm{~km}$ along the east-west axis and a width of up to $6 \mathrm{~km}$ Mograt is the largest of the Nilotic islands, covering an area of $102 \mathrm{~km}^{2}$ (Fig. 2). In 2013 the Mograt Island Archaeological Mission (MIAMi), then a cooperation of the Qatar-Sudan-Archaeological Project and Humboldt University of Berlin, was launched under the direction of Professor Claudia Näser as a continuation of the earlier work (Näser, 2006, 2008). Two specialized fieldwork seasons were conducted in 2014 and in 2014/15 to study the Late Prehistory (c. 12-5 ka BP) of the island, including its archaeology as well as its paleoecology (Dittrich and Gessner, 2014; Dittrich et al., 2015; Dittrich, in press a).

\section{PROSPECTS AND METHODOLOGY}

One of the prospects of the actual Late Prehistoric Survey as a sub-project of MIAMi was to reconstruct Mograt's early Holocene landscape which has been mainly conditioned by the oscillating activity and sediment loads of the two Nile courses as well as by the varying intensity of the surface run-off from local rains. To cover these issues a combined approach was used involving surface site recording and mapping (cf. Dittrich and Gessner, 2014), stratigraphic excavation (Dittrich et al., 2015), radiocarbon dating (Dittrich, in press a, table 1), the study of faunal remains as well as soil studies (Dittrich et al., 2015). The latter aimed at a better understanding of the environmental context through the description, measurement and interpretation of soil components and pedological features at a microscopic scale. Accordingly, during the second season soil block samples for micromorphological analysis were collected by S. Neogi in the field. The sampled sites were chosen according to the presence of both archaeological material and Quaternary sediments that often contained also ecofacts such as gastropods or animal bones. Since soil profiles themselves are archives of their own history, soil micromorphology is applicable to investigate environmental as well as cultural signatures preserved within buried soils and sediments. Part of the samples (from sites MOG105 and MOG107) has been studied in detail at the Charles McBurney Laboratory for Geoarchaeology in Cambridge the results of which are presented here. The remaining samples (from sites MOG086, MOG102, MOG114, and MOG116) as well as 10 OSL dating samples are currently stored at the Humboldt University of Berlin but are unavailable for research purposes on legal grounds. 


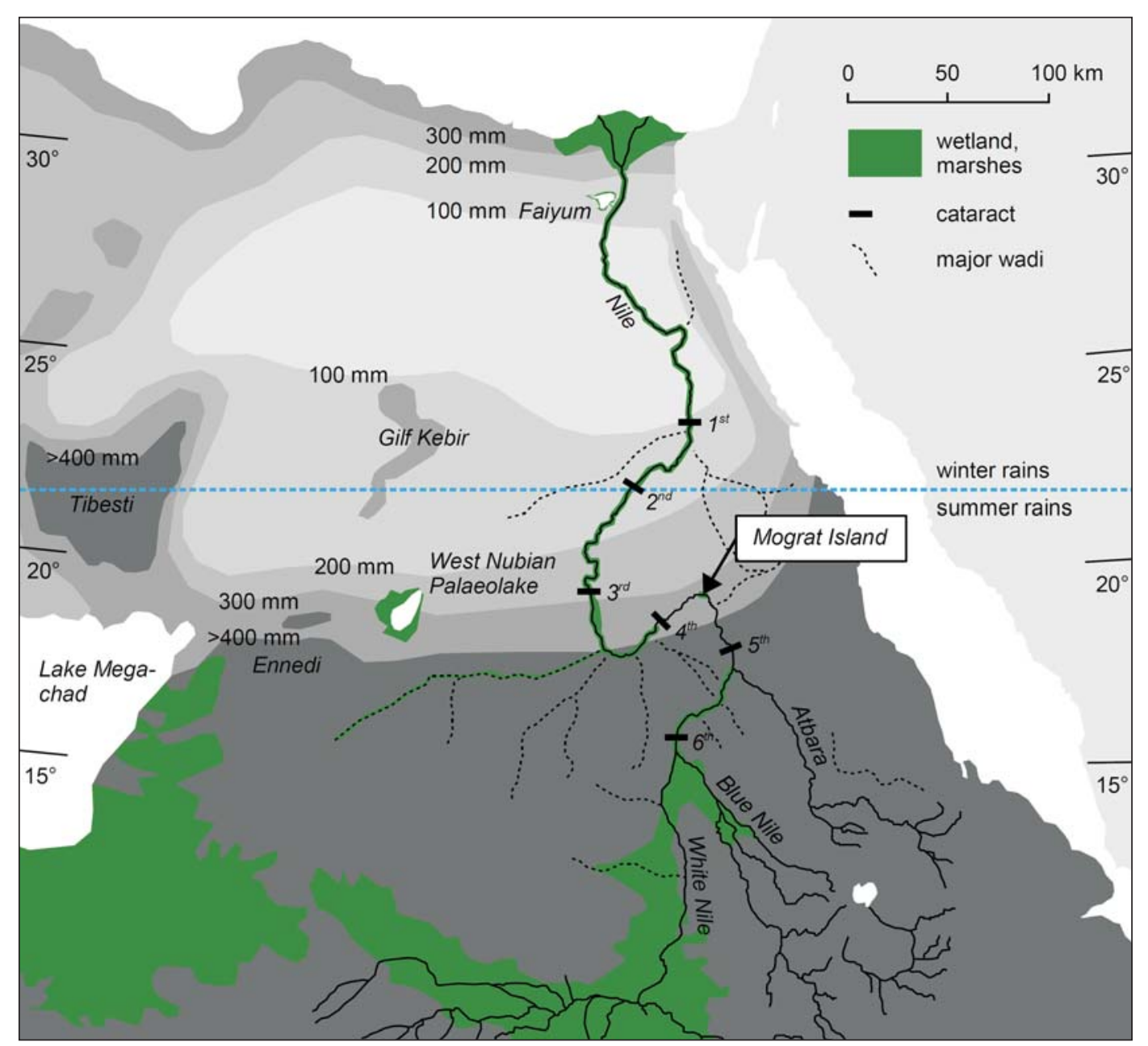

Fig. 1. Map of the Nile valley with reconstructed early Holocene precipitation (map: A. Dittrich; palaeoecological data based on Pachur and Altmann 2006: Figs 2.0.1, 5.2.2).

\section{TOPOGRAPHY OF THE STUDY AREA}

Mograt Island and most of its smaller flanking islands belong to the Precambrian basement complex at the northernmost extension of the Bayuda Massif(Whiteman, 1971). Therefore, the course of the Nile is mainly confined to deep cracks in the local tectonics but in some parts the southern Nile branch has developed true meanders (Figs 2, 3). Today this branch is much smaller than the northern one and in some years carries only a very low volume of water. During the archaeological survey, however, it became evident that this area is largely characterized by thick Late Pleistocene and Holocene alluvial deposits which are of great interest for studying the chronological sequence of the Quaternary Nile terraces.

Another interesting study area is the major crest of Mograt Island which is identical to its watershed running at its centre from east to west. At satellite images it is clearly visible due to its modern use as the main car track (Fig. 2, right). Despite its present appearance as stony desert with virtually no access to water (cf. Fig. 11), several archaeological sites dating to the mid-Holocene have been found on top of this elongated plateau (e.g. MOG105, Fig. 2, left). All of the highly dendritic wadi courses originate from this central crest draining surface water either to the northern or the southern Nile branch. The lower wadis frequently dissect the older Nile alluvium thus providing access to study the individual stratigraphy of the deposits (Fig. 4).

\section{RECONSTRUCTING THE HOLOCENE ALLUVIAL PLAIN}

From the deposits recorded so far, the highest Nile level can be assumed to have reached at least 10-12 m above the present level, which would have reduced the livable landmass to about $40 \%$ of its present dimensions (Fig. 3). As it can be made visible through a digital elevation model, the numerous small valleys along the Nile banks shaped by the tectonics and additionally cut down by wadis were potentially filled with water during each inundation. Concluding from similar observations for the early Holocene White Nile, sand dunes frequently blocked such valleys and, thus, closed off ephemeral lakes from the riverbed more permanently (Williams, 2009). Based on the evidence from Mograt Island at the Middle Nile it seems promising to study the nature of such an aligned lake system and how the local ecology must have changed twice, 

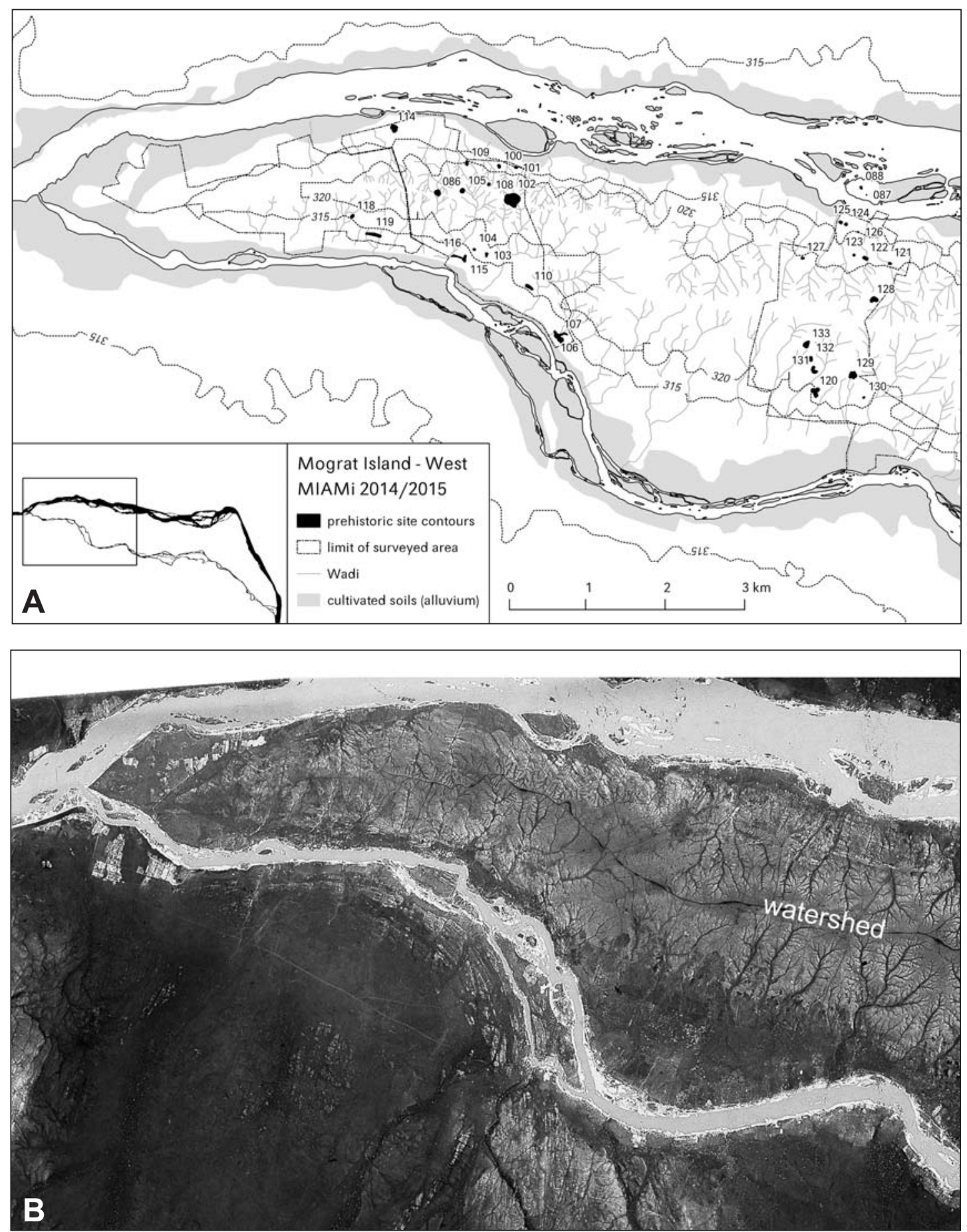

Fig. 2. Mograt Island, western part. Surveyed area and contours of recorded late prehistoric sites (A, map: A Dittrich), satellite image showing the highly dendritic wadi system (B, Corona image taken in 1965, rotated, colours inverted).

first with its emergence and secondly, with its subsequent drying-up.

Due to the restricted insular space and environments, in several instances alluvial deposits were observed to be interlocked with archaeological remains of different periods, allowing for a combined chrono-stratigraphic approach to study both cultural and climatic events (cf. Dittrich, 2013). Near Hajar al-Nur the early Holocene lake basin site (MOG107) was bordered by a mount strewn with numerous artefacts (MOG106) which was interpreted as the locality of an early to mid-Holocene settlement (Fig. 4, Dittrich and Gessner, 2014; Dittrich et al., 2015). Not far from this site and close to the homestead of Gharghara (MOG116, Fig. 2) a mid-Holocene occupational layer was found in a sandwiched position between two different stages of Nile sediment aggradation (Fig. 4, Dittrich et al., 2015; Dittrich, in press a). This layer must have been deposited during or shortly after a period of recession, thus indicating that significant oscillations of the Nile still occurred during the mid-Holocene. 


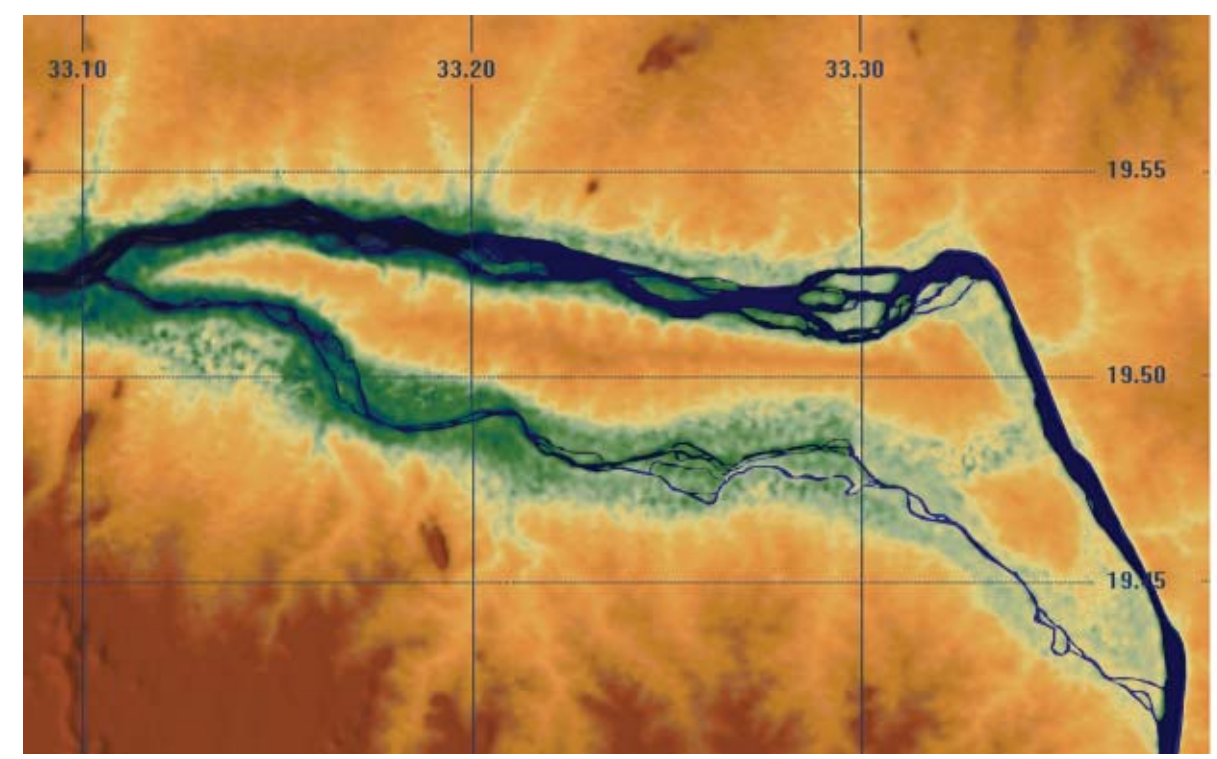

maximum Nile level simulation c. $10,000 \mathrm{BC}$ DEM based on SRTM

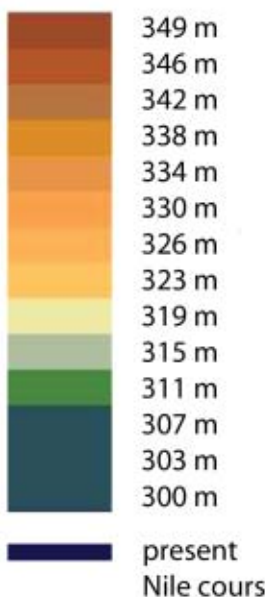

Fig. 3. Mograt Island. Maximum Holocene Nile level simulation assuming the alluvial plain to be extended to a height of 315-320 m. The gradual change of colours from light in the eastern part towards dark in the west is due to the rapid drop of $18 \mathrm{~m}$ of the river level to this direction (model: A. Dittrich; data based on SRTM).

\section{THE NILE TERRACES (MOG107)}

At the site MOG107, which is located on the older and higher Nile terrace (Figs 2, 4), the initial profile observation of a $3.5 \mathrm{~m}$ section had revealed two distinct phases of sedimentation (Dittrich and Gessner, 2014). In the lower part there are gravels and sands of an older terrace that contained few rolled Palaeolithic artefacts and should be dated to the Pleistocene (Fig. 5, layers marked in yellow). As a major discontinuity they are overlain by alluvium in the upper part (Fig. 5, layers marked in green) which contained at least two dry lake beds (Dittrich and Gessner, 2014: fig. 16; Dittrich et al., 2015: fig. 2). Gastropod shells from the upper dry lake bed have been dated to $9250-8960$ cal. $\mathrm{BC}$ while shells from the overlying alluvium gave a date of 8270-8020/8280-8250 cal BC (Dittrich and Gessner, 2014: table 2). Since these horizons suggested the former presence of a palaeolake or more permanent swamps, six soil block and bulk samples were collected for micromorphological and geochemical analyses from the profile 2 (Fig. 6).

\section{Description of the profile 2 "The Lake Profile" $\left(19^{\circ} 30.641^{\prime} \mathrm{N}, 3^{\circ} 10.027^{\prime} \mathrm{E}\right)$}

0-170 $\mathrm{cm}$ angular blocky, brownish yellowish (10YR 6/8) silt loam with large ped size, soil sample 1 collected at $145-151 \mathrm{~cm}$ (Nile alluvium)

170-195 cm compact, greyish (10YR 5/1) clay loam with frequent calcite nodules/calcretes, soil sample 2 collected at $171-179 \mathrm{~cm}$ (lower dry lake bed)

195-215 cm homogenous brownish yellow (10YR 6/6)

Table 1

Geochemical analysis of soil samples from the early Holocene lake site MOG107 and the inland shallow water sediments at the site MOG105

\begin{tabular}{|c|c|c|c|c|c|c|c|c|c|c|}
\hline \multirow{2}{*}{$\begin{array}{l}\text { Sample } \\
\text { number }\end{array}$} & \multirow{2}{*}{$\begin{array}{c}\text { Depth } \\
\text { (cm) }\end{array}$} & \multirow{2}{*}{$\begin{array}{c}\mathrm{pH} \\
\text { value }\end{array}$} & \multirow{2}{*}{$\begin{array}{c}\text { Electron } \\
\text { conductivity } \\
(\mathrm{ms} / \mathrm{cm})\end{array}$} & \multirow{2}{*}{$\begin{array}{c}\text { Magnetic } \\
\text { susceptibility } \\
\text { (SI) }\end{array}$} & \multicolumn{3}{|c|}{ Particle size analyses } & \multicolumn{3}{|c|}{ Loss-on-ignition } \\
\hline & & & & & $\%$ Sand & $\%$ Silt & $\%$ Clay & $\%$ Organics & $\% \mathrm{CaCO}_{3}$ & $\%$ Mineral \\
\hline \multicolumn{11}{|c|}{ MOG107 profile 2} \\
\hline 1 & $145-151$ & 8.73 & 3.48 & 418.8 & 38.6 & 57.6 & 3.8 & 8.0 & 4.5 & 87.5 \\
\hline 2 & $172-179$ & 7.99 & 10.14 & 227.7 & 7.6 & 83.1 & 9.3 & 10.2 & 3.0 & 86.8 \\
\hline 3 & 195-203 & 8.38 & 1.71 & 90.0 & 58.6 & 39.1 & 2.3 & 2.0 & 0.5 & 97.5 \\
\hline 4 & $243-250$ & 8.24 & 3.00 & 67.9 & 66.6 & 29.8 & 3.5 & 1.7 & 0.3 & 98.0 \\
\hline 5 & $265-277$ & 9.49 & 0.99 & 82.8 & 55.2 & 41.0 & 3.9 & 2.4 & 0.6 & 96.9 \\
\hline 6 & $320-327$ & 8.88 & 2.40 & 26.1 & 40.4 & 55.6 & 4.0 & 3.0 & 0.6 & 96.4 \\
\hline \multicolumn{11}{|c|}{ MOG105 section $\mathrm{S}$} \\
\hline 3 & $40-48$ & 7.77 & 30.00 & 74.6 & 35.0 & 59.4 & 5.6 & 5.5 & 15.6 & 78.9 \\
\hline 2 & $65-73$ & 7.56 & 33.00 & 41.7 & 26.6 & 68.2 & 5.2 & 6.4 & 19.9 & 73.7 \\
\hline 1 & $70-78$ & 7.72 & 36.16 & 22.2 & 26.9 & 65.7 & 7.4 & 4.2 & 27.2 & 68.6 \\
\hline
\end{tabular}



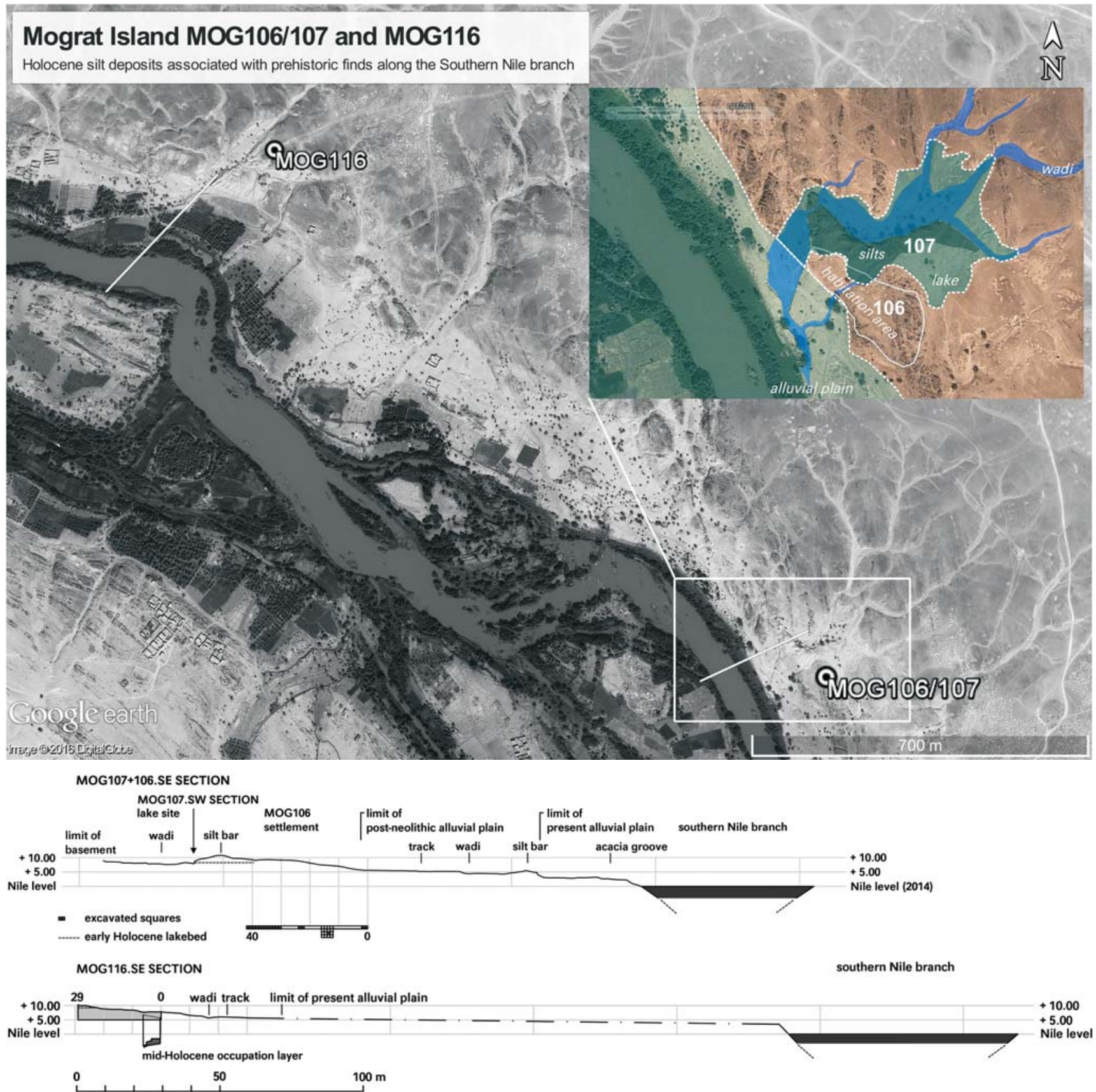

Fig. 4. Mograt Island, western part. Satellite image with the location of the sites MOG106/107 and MOG116 along the southern Nile branch, the assumed extension of the early Holocene lake at MOG107 (top, right) and the SE sections through each site and the adjoining Nile River bank (mapping: A. Dittrich, K. Gessner; satellite image: Google Earth).

sandy silt loam, soil sample 3 collected at $195-203 \mathrm{~cm}$

215-227 cm compact, greyish (10YR 5/1) clay loam with frequent calcite nodules/calcretes

$227-237 \mathrm{~cm}$ homogenous yellowish brown (10 YR 5/8) sandy silt loam

$237-252 \mathrm{~cm}$ fine sand mixed with gravels and pebbles, soil sample 4 collected at $243-250 \mathrm{~cm}$

252-292 cm homogenous yellowish brown (10 YR 5/6) sandy silt loam with some gravels, soil sample 5 collected at $265-277 \mathrm{~cm}$

$292-330 \mathrm{~cm}$ colluvium with fine sand and few calcite pseudomorphs, soil sample 6 collected at $320-327 \mathrm{~cm}$

$330+\mathrm{cm} \quad$ calcareous bedrock

\section{Soil micromorphology}

Sample 1.-The soil thin section of sample 1 has revealed horizontally bedded a pedal soil material composed of fine sandy silty clay. The sediments are either coarse or very fine with the finest material corresponding to clear but thick bands $(<1 \mathrm{~cm})$ of disrupted sedimentary crusts (Fig. 7). 
Embedded in the groundmass, there are well sorted, very fine, single grain minerals that include sub-angular quartz grains, rectangular shaped mica and few sub-rounded tourmaline. The organic content is quite high in the whole thin section $(<30 \%)$. It contains dark brown amorphous organic fine materials, humified plant tissues as well as cells and cell wall residues.

Bioturbation and faunal activities are quite common as passage features with voids and channels filled with aggregates of groundmass material, often disrupting the sedimentary crusts. Textural pedofeatures are otherwise very common with frequent alluvial clay in the fabric. This includes allochthonous fragments of limpid clay and continuous coatings of impure clay around voids and within the micromass (Fig. 8). Redoximorphic features are also equally dominant with frequent moderately to highly impregnated typic orthic to dendritic nodules and coating of moderately to highly impregnated iron hydroxide around voids and channels. Crystalline pedofeatures are few with some embedded nodules of secondary calcium carbonates and micrite hypocoatings.

From the microscopic observation it is quite evident that the whole fabric is clearly sedimentary with a banded distribution pattern and thick sedimentary crusts (cf. Pagliai and Stoops, 2010). These rather thick sedimentary crusts, which are composed of very fine material, have horizontal microlaminations within them, which further suggest overbank flooding and water logging conditions (cf. Mücher et al., 2010). Repetitive events of such floods resulted in the formation of these alternative sedimentary crusts (cf. Pagliai and Stoops, 2010). Subsequent pedogenesis after episodes of flooding is very much evident. These pedogenic signatures have been found to be superimposed on top of such sedimentary aspects.

Faint pedogenic development of structures and channels and root pseudomorphs are suggestive of stability in the system (cf. Kooistra and Pulleman, 2010). Pedogenesis is supported by the abundant presence of textural pedofeatures (cf. Kühn et al., 2010). While the impure clay coatings could have been the product of alluvial aggradation, the allochthonous fragments of limpid clay suggest that these had been locally eroded, moved and recycled from a very well developed "B" horizon (cf. Fedoroff et al., 2010). Amorphous features suggest alternating wet and dry conditions (redox) and frequent fluctuations of the groundwater table or repeated floods of high magnitude (cf. Lindbo et al., 2010; Schaetzl and Anderson, 2005).

In sum, the micromorphological observations suggest soil formation in an active flood plain condition. The results of flood events, in wash deposits, humid environmental conditions and post-depositional disruption by soil fauna are well observed in the thin section. As also seen in the presence of numerous calcified plant roots, after its deposition this horizon would have been most suitable for the growth of plants and therefore may have been attractive for farming during each periodical drying-up of the alluvium.

Table 2

Mograt Island (Sudan). Radiocarbon dated sequence for the shifting Holocene Nile rivers cape (for a complete list of radiocarbon dates cf. Dittrich, in press a: table 1)

\begin{tabular}{|c|c|c|c|c|c|}
\hline Years cal. BC & $\sim$ Mean cal. BP & $\begin{array}{l}\text { Human presence } \\
(+ \text { dated, } \circ \text { relics })\end{array}$ & $\begin{array}{l}\text { Nile terrace (upper) } \\
(+ \text { dated })\end{array}$ & $\begin{array}{l}\text { Nile terrace (lower) } \\
\qquad(+ \text { dated })\end{array}$ & $\begin{array}{l}\text { High plateau (rainfalls) } \\
(+ \text { dated })\end{array}$ \\
\hline & & $\circ$ & $\uparrow$ & annual flood peaks & \\
\hline$<5380$ & $<7.4 \mathrm{ka}$ & $\circ$ & slope erosion & $\begin{array}{c}\text { Nile meandering/ } \\
\text { downcutting }\end{array}$ & \\
\hline $5470-5380$ & $\sim 7.4 \mathrm{ka}$ & $\circ$ & $\downarrow$ & $\downarrow$ & $\begin{array}{c}\text { shallow water } \\
\text { (+ shells in situ/ in deposits) }\end{array}$ \\
\hline $5530-5480$ & $\sim 7.5 \mathrm{ka}$ & + & & & $\begin{array}{c}\text { shallow water } \\
\text { (+ shells in situ/ in deposits) }\end{array}$ \\
\hline $5620-5550$ & $\sim 7.6 \mathrm{ka}$ & + & & & \\
\hline $5830-5700$ & $\sim 7.8 \mathrm{ka}$ & $\circ$ & (dried up) & $\begin{array}{l}\text { swampy floodplain } \\
(+ \text { shells in deposits) }\end{array}$ & \\
\hline $6080-6010$ & $\sim 8.1 \mathrm{ka}$ & $\circ ?$ & & & $\begin{array}{c}\text { shallow water } \\
(+ \text { shells in situ/ in deposits) }\end{array}$ \\
\hline \multirow[t]{2}{*}{$6480-6410$} & $\sim 8.5 \mathrm{ka}$ & & & $\begin{array}{c}\text { swampy floodplain } \\
(+ \text { mature shells in situ })\end{array}$ & \\
\hline & & & & $\downarrow$ & \\
\hline \multirow[t]{2}{*}{$7450-7320$} & $\sim 9.5 \mathrm{ka}$ & + & \multicolumn{2}{|c|}{ (downcutting of the Nile River) } & \\
\hline & & & $\uparrow$ & & \\
\hline \multirow[t]{2}{*}{$8300-8020$} & $\sim 10.3 \mathrm{ka}$ & + & $\begin{array}{l}\text { periodical lake flooding } \\
(+ \text { shells in situ })\end{array}$ & & \\
\hline & & & $\downarrow$ & & \\
\hline $9350-8950$ & $\sim 11.4 \mathrm{ka}$ & $\circ ?$ & $\begin{array}{l}\text { permanent lake } \\
(+ \text { shells in situ })\end{array}$ & & \\
\hline \multirow[t]{3}{*}{$>9300$} & $>11.4 \mathrm{ka}$ & $\circ$ & periodical lake flooding & & \\
\hline & & & permanent lake & & \\
\hline & $?>12 \mathrm{ka}$ & & \multicolumn{2}{|c|}{ boundary to cemented clays and dune sands } & \\
\hline
\end{tabular}




\section{MOG107 SECT. 3 Legend}

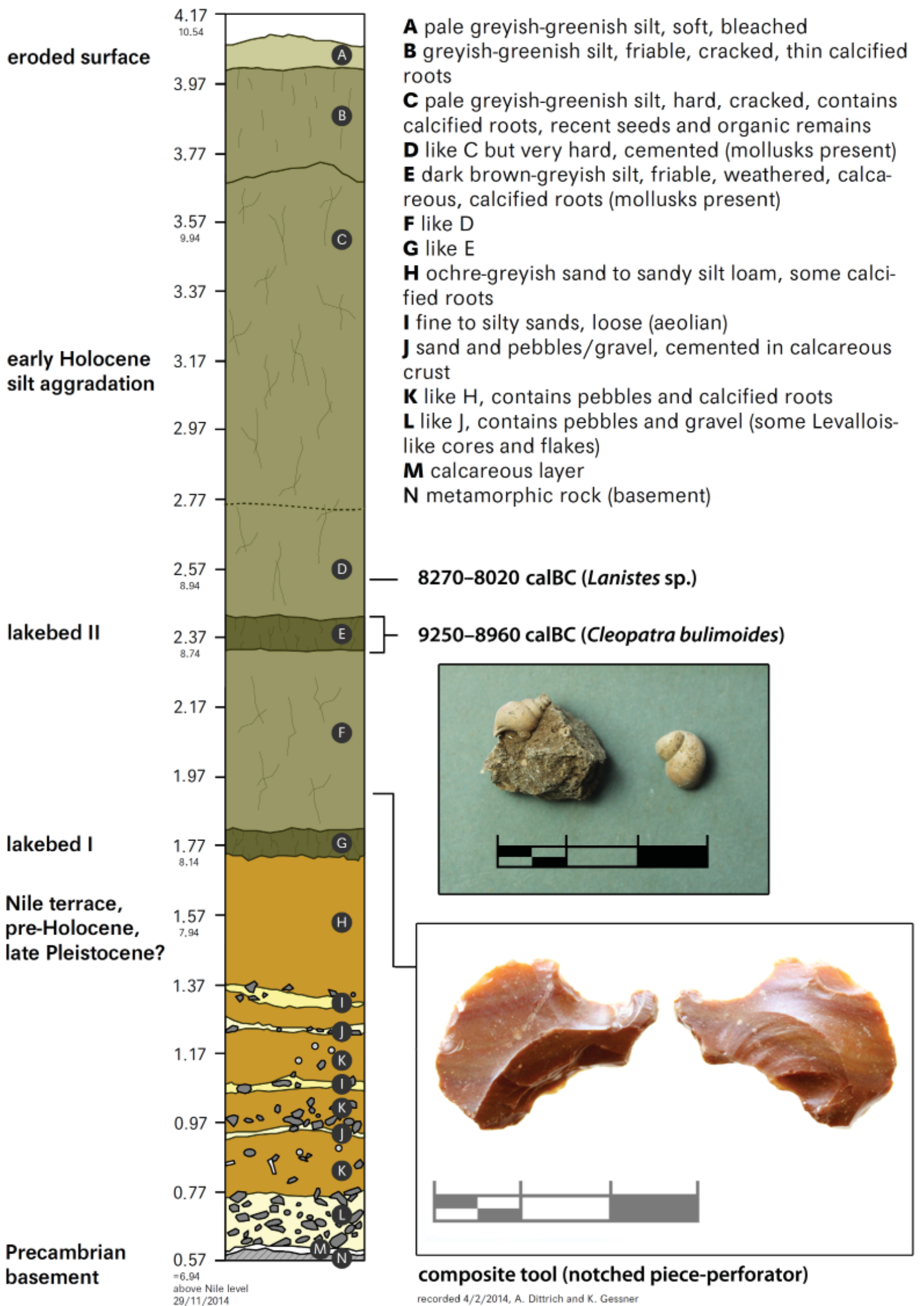

Fig. 5. Mograt Island, site MOG107. Stratigraphic record with the position of radiocarbon dated mollusk shells and of a singular lithic tool, for the location of the section cf. Fig. 4 (recording and drawing by A. Dittrich, K. Gessner; scale in m above local 0 and above Nile level in 2014 ). 


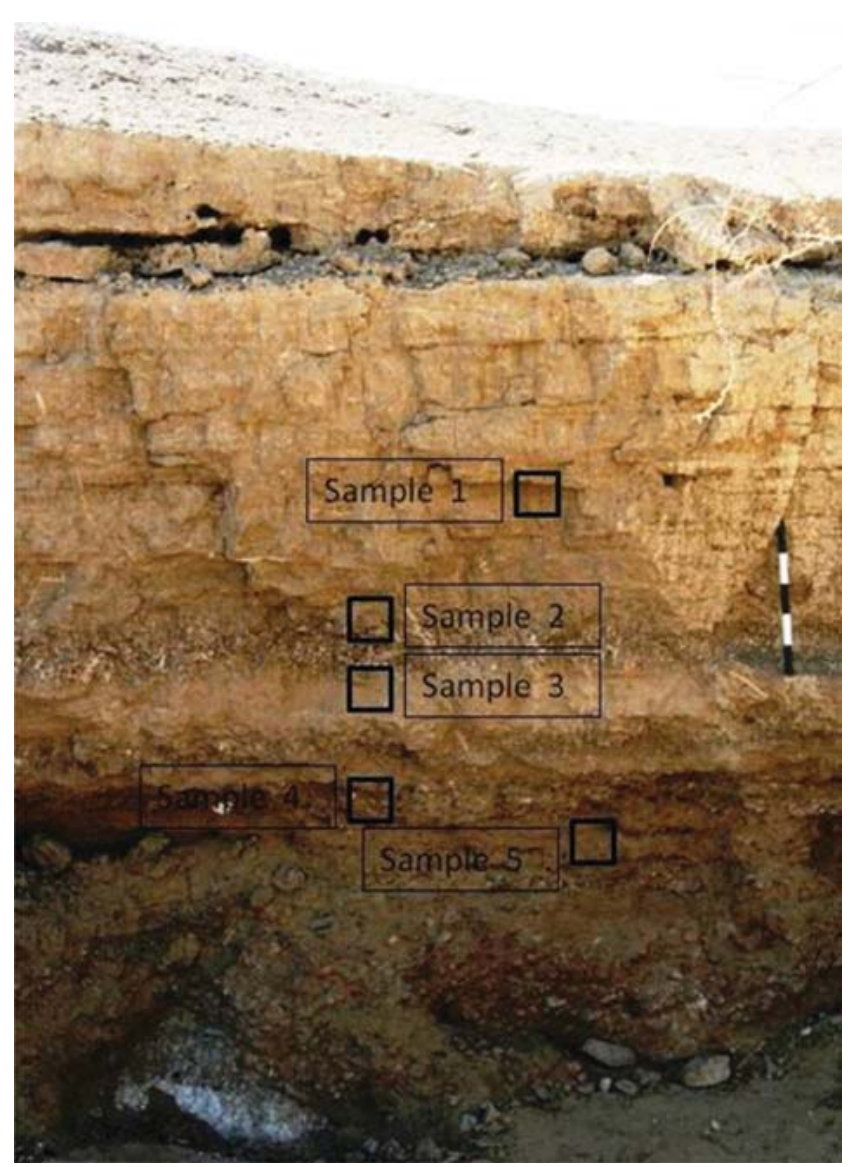

Fig. 6. MOG107, profile 2: location of soil samples 1-5 (photo S. Neogi).

Sample 2.-Microscopic observation from this soil sample, which was collected from an apparent dry lake bed (Fig. 6), shows sub-angular blocky microstructure with moderate porosity. The yellowish grey coloured matrix is composed of sandy loam. The embedded abundant silt-sized mineral grains in the groundmass (Table 1) are of various lithologies, sub-rounded to round in shape and randomly sorted. Quite distinctive of these minerals are highly abundant rectangular shaped quartz, mica, feldspar, pyroxenes and other isotropic opaque minerals. Anthropogenic inclusions are non-existent. The organic contents are moderate $(<10 \%)$, observed as dark brown highly humified amorphous fine material.

There is evidence of little bioturbation with dark organic pigmentations and moderate organic remains. Otherwise, a wide range of pedofeatures are observed, with crystalline pedofeatures being dominant with a crystallitic b-fabric. These include calcium carbonate coatings and hypocoatings, nodules of micrite and dense complete infilling of channels. Amorphous pedofeatures are impressive and generously abundant as well and are present as mottles, highly impregnated dendritic and orthic nodules of iron hydroxide and manganese (Fig. 9), often superimposed on the existing crystalline pedofeatures as stains. Quite interestingly, textural pedofeatures are also present either as little flakes (150-200 $\mu)$ of limpid and microlaminated clay with an overall distribution of impure clay in the system.
The intertwining nature of crystalline and redoximorphic pedofeatures to a high degree has been crucial in the identification of this soil horizon from a water-logged and subsequent drying out condition. Experience of long-standing water logged conditions would have helped in the development of characteristic concentrations of iron called "mottles" and highly impregnated dendritic nodules (cf. Kovda and Mermut, 2010; Lindbo et al., 2010). Abundant crystalline pedofeatures are suggestive of re-precipitation of calcium carbonates due to the "drying out" phase that would have cropped up later (cf. Durand et al., 2010). The presence of textural pedofeatures post-dates the "drying out" phase when soil illuviation processes became active as well. Subsequent influx and infiltration of alluvial clay and pedogenesis suggest stability in the system (cf. Kühn et al., 2010).

Samples 3, 4 and 5.-Collected from the middle part of the profile 2 (Fig. 6), the microscopic observations from soil sample 3 revealed apedal soil materials without clods and fragments. The fabric is composed of coarse homogenous sand with moderate porosity. The groundmass is made up

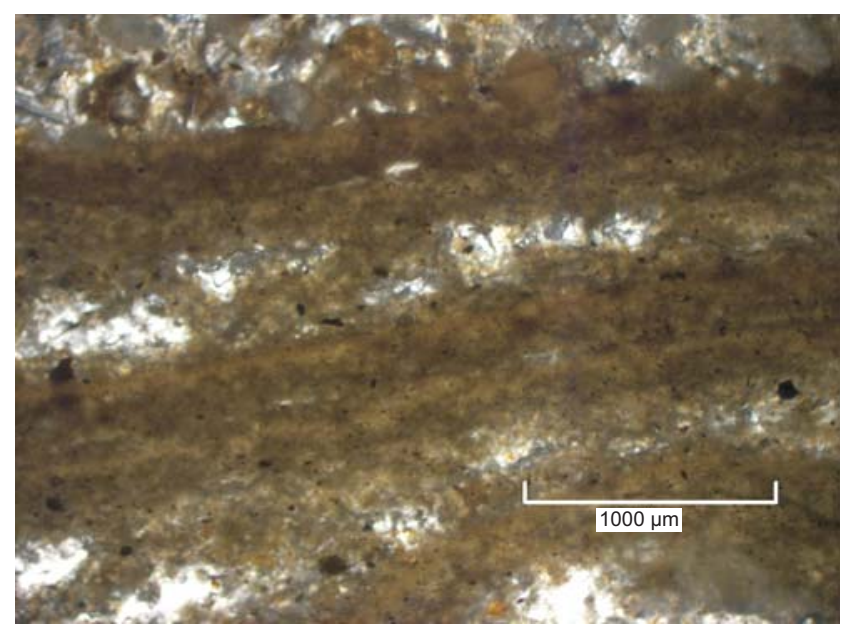

Fig. 7. MOG107, sample 1. Sedimentary water crusts with horizontal laminations (XPL) (photo S. Neogi).

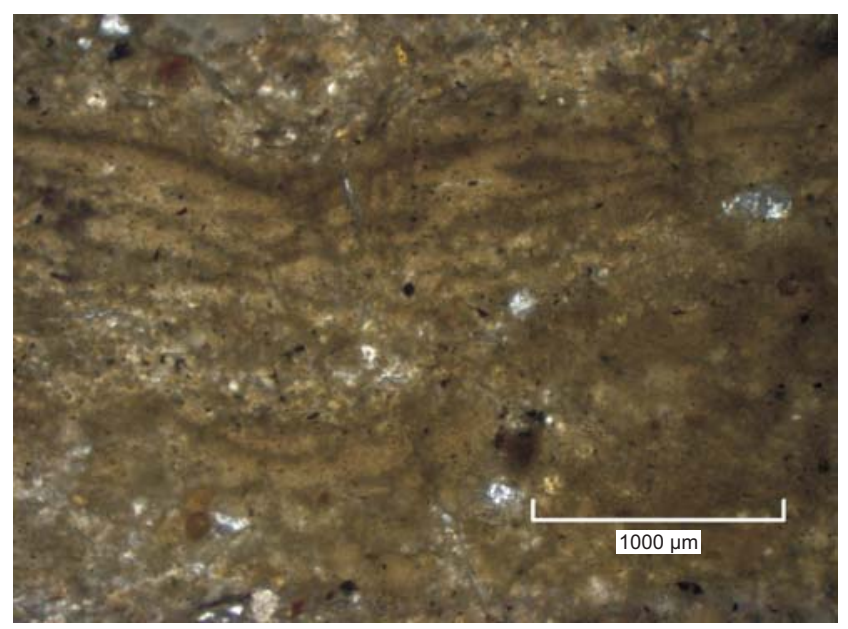

Fig. 8. MOG107, sample 1. Presence of impure clay within the groundmass (XPL) (photo S. Neogi). 


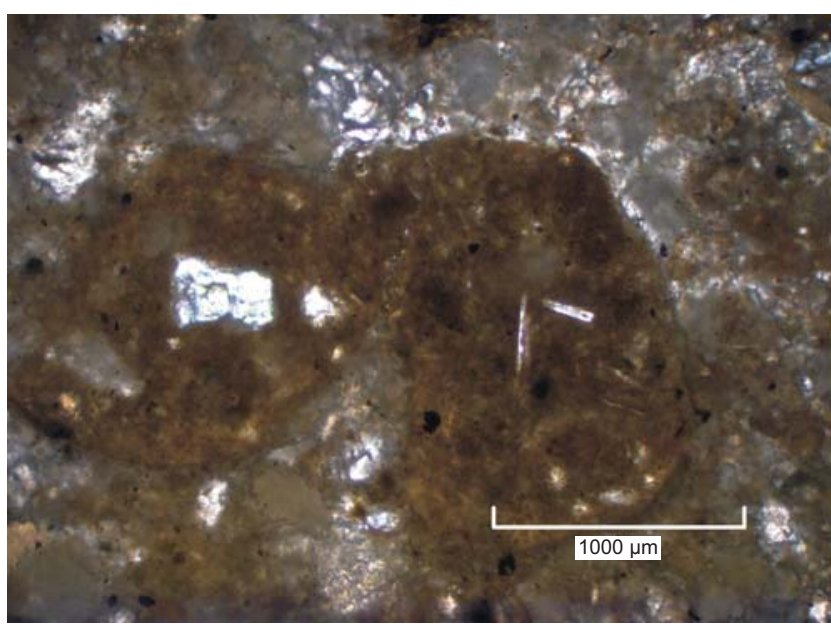

Fig. 9. MOG107, sample 2. Dark amorphous orthic nodule (PPL) (photo S. Neogi).

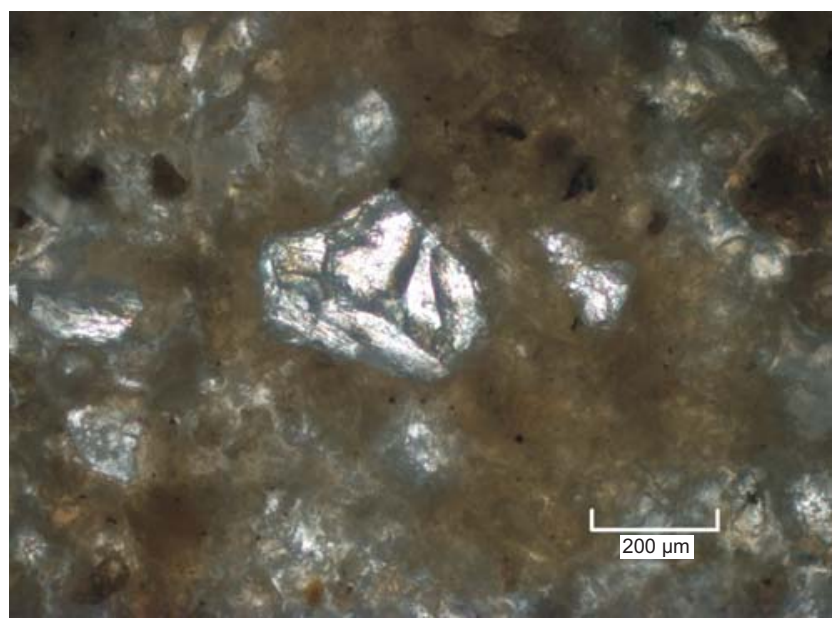

Fig. 10. MOG107, sample 3. Sand-sized particles with impure clay around (PPL) (photo S. Neogi).

of mostly single mineral grains of various lithologies with dominant well-sorted rounded to subrounded quartz sand grains and rectangular shaped mica. The organic content is little to moderate in the whole thin section $(<10 \%)$, visible as dark brown amorphous organic fine materials.

Textural pedofeatures are rare, visible as impure clay coatings around voids and minerals and very few fragments of limpid clay with superimposition of impure clay on them. Amorphous pedofeatures are present too as dendritic nodules of moderately impregnated iron hydroxide. Through typical crystalline pedofeatures are not present, the sand sized particles have been cemented by fine calcium carbonates.

All these three samples are far richer in coarser material (Table 1) and mainly include rocks and minerals from various lithologies. From the presence of bridged grain microstructures and enaulic distribution patterns, it is apparent that the groundmass is composed of fine to medium sized sand. The shape of these embedded sands suggests that these are dune deposits. The presence of some sedimentary facies and water-crusts combined with the presence of some limpid clay, however, suggests that these coarser dune deposits subsequently received some influx of alluvial deposition as well (Fig. 10). Also from the stratigraphic section (Fig. 5) it is evident that the aeolian deposition was repeatedly interrupted by episodes of rapid flooding from the surface run-off and the deposition of colluvial gravel layers.

Sample 6.-This thin section was sampled from towards the base of the Lake Profile, just above the strata of calcareous rocks. The groundmass has a close to single spaced porphyric distribution pattern. The coarse material forms a heterogeneous unsorted assemblage of igneous rocks, minerals derived from the weathering of the limestone bedrock and limestone gravels. Other identified minerals include unsorted and rounded plagioclase feldspar, pyroxene and basalt. There are larger limestone rock fragments of an overwhelmingly fine calcareous fabric. The organic components include shell fragments, inherited from the limestone bedrock. The micromass has a weak calcite crystallitic b-fabric.

The characteristic pedofeatures show secondary formation of calcium carbonate within the profile. This horizon is interpreted as colluvium consisting of heterogeneous sediment and characterized by various textures and matrix colours. Besides this, there is abundant evidence for the incorporation of volcanic tephra throughout the thin section. Its occurrence is probably connected to previous activities of the Bayuda volcanic field.

\section{THE CENTRAL PLATEAU (MOG105)}

The site MOG105 is located at the central plateau of Mograt Island roughly $2 \mathrm{~km}$ inland from either Nile bank (Fig. 2, left). This area is mainly deflated and characterized by a desert stone pavement consisting of pebbles (Fig. 11) which are commonly embedded in a wind-blown silt layer (Fig. 12; cf. Dittrich and Gessner, 2014). Archaeological remains found at the surface, however, indicate various human activities such as grinding and cooking during prehistory.

From this and other sites in the vicinity a number of indicators for the palaeo-environments were found such as bones of gazella, hippopotamus and domestic sheep, or gastropod shells (Dittrich et al., 2015: table 3). The latter include the species Zootecus insularis, Pila sp., Lanistes sp. and Bellamya unicolor which would either indicate grassland, nearby swamps and permanent water bodies. Human and biological activities have been dated from 7120 cal. $\mathrm{BC}$ onwards, while the majority of the radiocarbon dates form a cluster between 5620 and $5380 \mathrm{cal}$. BC (Dittrich et al., 2015: table 4). As we wanted to understand what made this place attractive in the past we took three samples for the study of soil micromorphology, especially from a soft and powdery whitish to greyish sediment rich in mica that constituted the fill of a large surface depression (Figs 13, 14). According to field observations an explanation for the genesis of this unstratified sediment seemed to be lacking. 


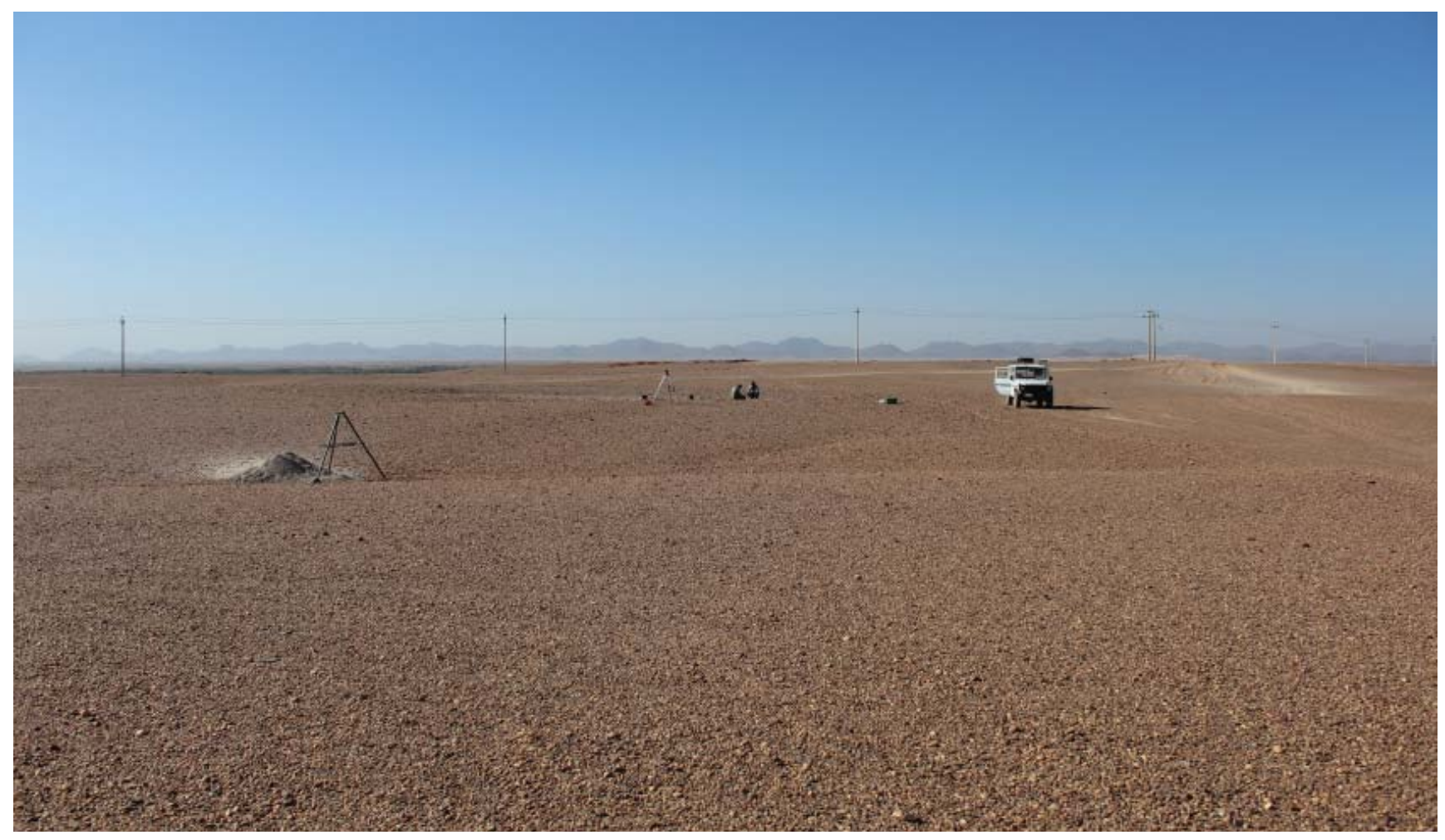

Fig. 11. Overview of site MOG105 during test excavation, the large shallow depression in the surface is clearly visible (photo A. Dittrich).

\section{Description of Western Section $\left(1^{\circ} 31.701^{\prime} \mathrm{N}, 3^{\circ} 9.330^{\prime} \mathrm{E}\right)$}

0-10 cm very fine pale brownish (10YR 7/3) sand deposit with some gravels

$10-53 \mathrm{~cm}$ very loose, slightly darker than the top layer (10YR 6/3), micaceous deposit, soil sample 3 collected at $40-48 \mathrm{~cm}$

53-63 cm compact whitish (7.5YR 8/1) sediments

63-90 cm more compact micaceous deposit with gravels and water-lain signatures, soil sample 2 collected at $65-73 \mathrm{~cm}$, soil sample 1 collected at $70-78 \mathrm{~cm}$

\section{Soil micromorphology}

Samples 1 to 3.-Microscopic observations from the three samples show apedal soil material. With a very little porosity, the grey coloured finer matrix is composed of very fine clay sized carbonate material. The embedded mineral grains in the groundmass are of various lithologies, sub-rounded to round in shape, randomly sorted and are mostly igneous minerals of volcanic origin. Quite distinctive are highly abundant rectangular shaped quartz, mica, feldspar and rare hornblende. Anthropogenic inclusions are rare and include few bone fragments, while the organic contents are moderate $(<10 \%)$, observed as dark brown highly humified amorphous fine material which is indicative of the prevalence of vegetation cover (cf. Stolt and Lindbo, 2010).
Evidence of bioturbation is noticeable with channels infilled with organic aggregates and dark organic pigmentations that can be attributed to earthworm activity. Otherwise, a wide range of pedofeatures are observed with crystalline pedofeatures being dominant. These include calcium carbonate coatings and hypocoatings, nodules of

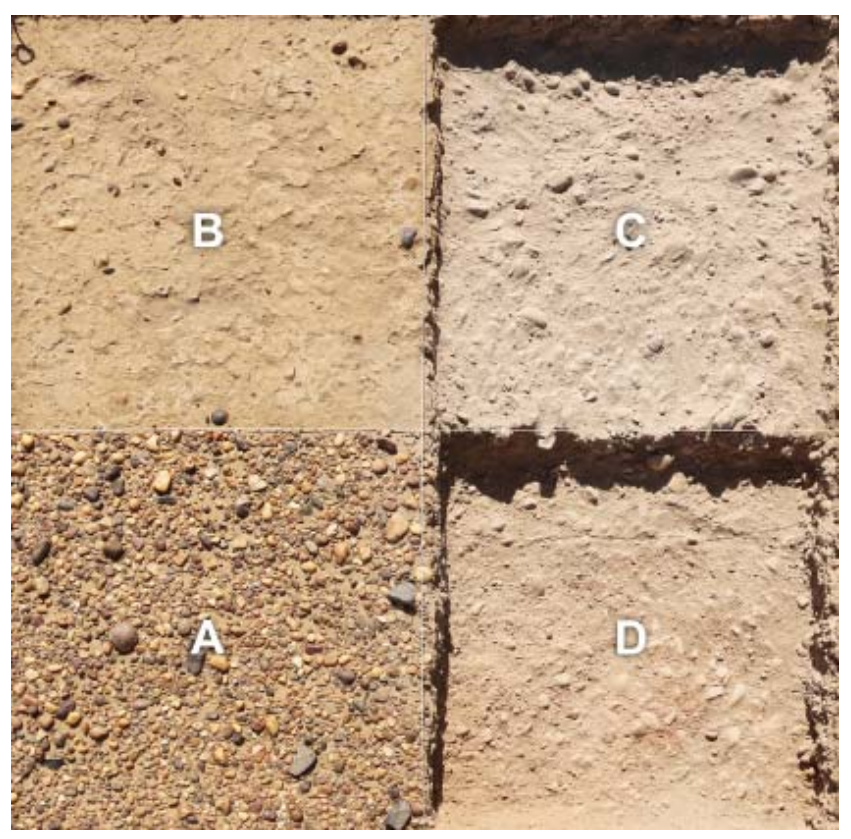

Fig. 12. MOG105, test trench 1 . The excavated scheme shows the sequence of the pebble cover at the surface (A), grey wind-blown silts (B) changing to light grey sediments of local origin $(C, D)(2 \times 2 \mathrm{~m}$, view to the south, photo M. Ehlert). 
MOG105 TEST TRENCH 1, SECT. W

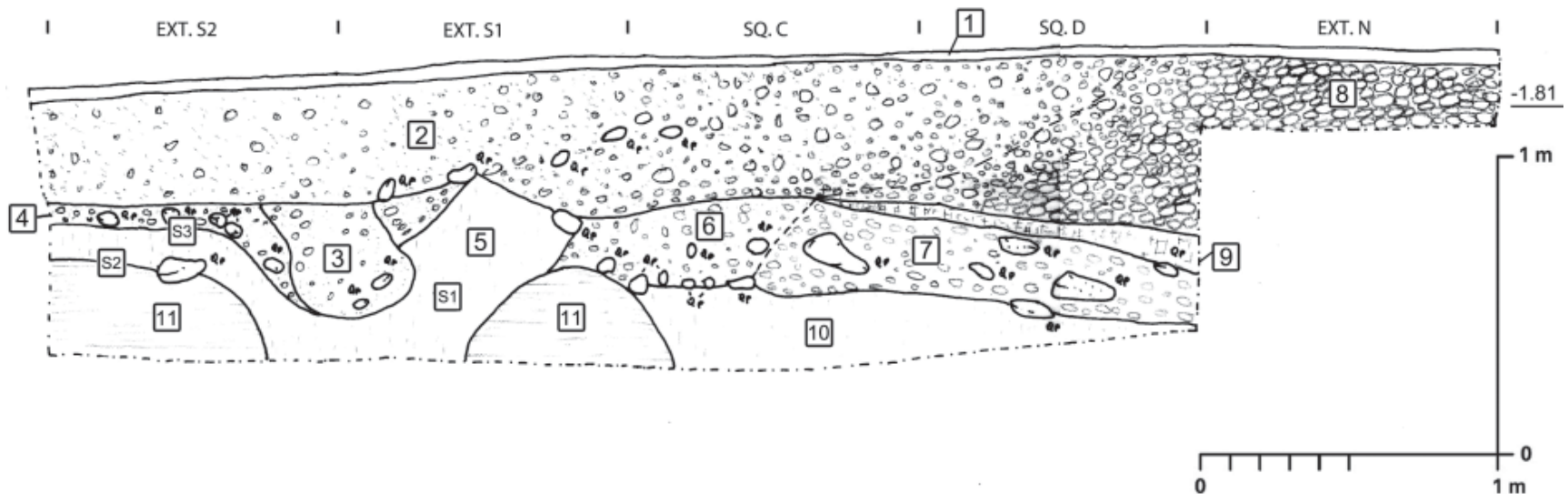

Fig. 13. MOG105, test trench 1 , section W. The tightly packed sterile pebble deposits $(7,8)$ resting on silts $(9,10)$ are disturbed and reworked towards the centre of the depression to the left, filled with laminated silts (11) and a fine white-greyish sediment (2-6; drawing by M. Ehlert, datum in $\mathrm{m}$ below local 0); EXT.S1, EXT.S2, EXT N, SQ.C, SQ.D - the archaeological excavation units, S1-S3: soil samples.

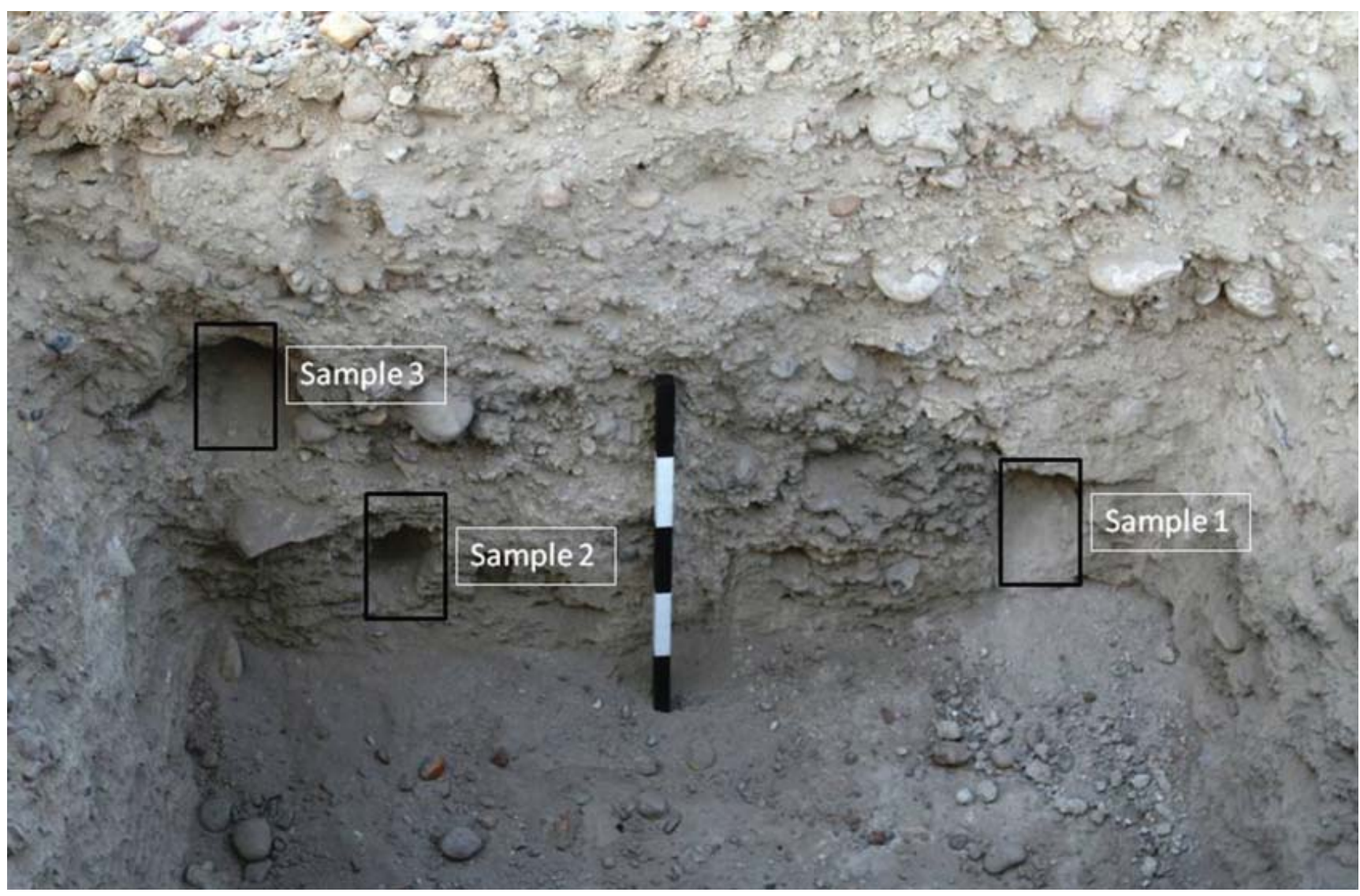

Fig. 14. MOG105. Location of soil samples $1-3$ (photo S. Neogi).

micrite and dense complete infilling of channels. The finer matrix is welded together by carbonate cement (in solution), hence exhibiting crystalline b-fabric (Fig. 15). Amorphous pedofeatures are notable too and are present as moderately impregnated dendritic nodules of iron hydroxide and manganese, often superimposed on the existing textural and crystalline pedofeatures as stains.

Similar to site MOG107, particle size once again indicates the presence of sandy silt loam in the samples
(Table 1). The rounded to sub-rounded nature of deposits characterized by their weathered surfaces and welded together by finer materials suggest that these have been rolled by the action of water, reworked and re-deposited.

As a result it can be concluded that the fine greyishwhite materials originated from environmental sources, namely from carbonate bedrocks. The calcitic pedofeatures are mostly the product of calcium carbonate dissolution and their re-precipitation in soil solution, percolating down-pro- 


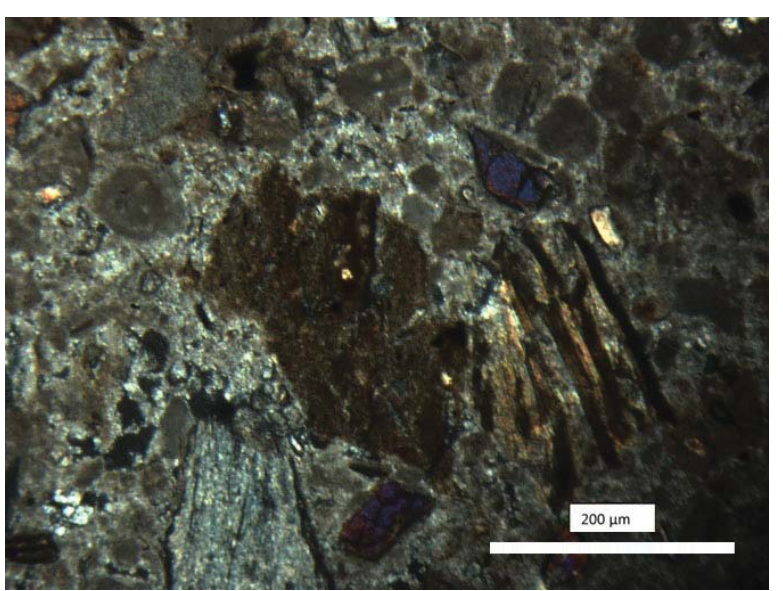

Fig. 15. MOG105. Welding of the finer matrix by carbonate cement (XPL) (photo S. Neogi).

file through soil pores or fissures (cf. Durand et al., 2010; Sehgal and Stoops, 1972). The presence and distribution pattern of such a whole range of calcite features could have arisen from the fast saturation of the soil by water that was rich in calcium and dried quickly (cf. Pal et al., 2000; Yaalon, 1983).

The presence of iron nodules and staining, at different degrees of impregnation, is evidence of the fluctuating groundwater level (cf. Gerrard, 1992; Kraus, 1999; McCarthy and Plint, 1998; Schaetzl and Anderson, 2005). The different forms of iron nodules are indicative of multi-episodes of alternating wet-dry-post depositional conditions. For example, the formation of the observed dendritic manganese nodules might have been facilitated by the ensuing period of high water retention (cf. Kovda and Mermut, 2010; Schaetzl and Anderson, 2005; Simonson and Boersma, 1972) on the overlying level after the sediment or weakly developed soil was covered, suggesting prevailing wet conditions (cf. Banesz et al., 1995). The co-existence of crystalline and redoximorphic pedofeatures throughout further suggest subjection to repeated seasonal wet-dry alterations (cf. Bridge, 2003). The existence of few recent and drought-resistant plants in the field during excavation indicates that still today the spot is capable to store rain water.

\section{CONCLUSIONS}

The different water regimes studied through detailed stratigraphic observation and micromorphological analysis for two selected sites at Mograt Island reveal first insights into the Holocene climatostratigraphic sequence of the Middle Nile (Table 2).

At site MOG106/107, which is located on the older and higher Nile terrace, profile observation had already revealed the presence of two distinctive layers that were thought to present at least two dry lake beds. Gastropod shells from the upper lake bed have been dated to the $10^{\text {th }}$ millennium cal. BC while shells from the alluvium above this level gave a date to the $9^{\text {th }}$ millennium cal. BC. The lower lake bed is likely to predate $9300 \mathrm{cal}$. BC by a few centuries which would be still within the limits of the Holocene period. While the supposed lake beds suggested the presence of a palaeolake and swampy conditions, the microscopic study of the thin sections from these sediments has been able to detect their subsequent altering due to a profound environmental change. Post-depositional disruption by soil fauna is an indication to the presence of humic soils and a plant cover which would have made the place attractive also for the cultivation or the gathering of annual plants between flooding events. Since presently at Mograt Island and also in other places along the Sudanese Nile valley early Holocene alluvial soils are a sought-after resource for improving recent farmland, the scenario of a lake periodically drying up offers a perfect starting position for plant cultivation (Dittrich, in press b). However, in the study area the latter is so far indicated only by the proof of disrupted humic soils as well as the archaeological record of interlocked human occupational remains hinting to grinding and cooking activities.

The second studied site MOG105 is located inland at the highest part of the island which emerges as a flat pebble plain today. Although this arid spot seems to be characterized by the fast surface runoff of rain water, the sediment profile of a test trench studied through three thin sections suggests the periodical storage of shallow water and the subsequent drying-up during the Holocene. From this emerges the picture of a rain-fed shallow water pond that was surrounded by dense vegetation sustaining a humic top soil. The access to water in a surface depression, comparable to historically known hafirs which are important for animal watering, would explain human interest in the spot represented by numerous archaeological remains intermingled with the sediments. The wide range of radiocarbon samples dated to the mid of the $6^{\text {th }}$ millennium cal. BC indicate a significant mid-Holocene event with pronounced rainfalls followed by dry seasons.

These two sites could be viewed as the start and end points of a profound change of Mograt's environments from the early to the mid-Holocene (Table 2), triggering the long term shift from the exploitation of aquatic resources and annual plants growing in large drying-up flood plains to the natural flood and basin cultivation as well as the herding and watering of domestic animals. Thus, geoarchaeological evaluations have shown that there is a varied hidden landscape context for each of the studied sites, which indicates a symbiotic relationship with the Nilotic environmental system.

\section{REFERENCES}

Bánesz, L., Hromada, J., Kozlowski, J., Sobczyk, K., Pawlikowski, M., 1995. Site Formation Processes in Loess Areas: A case study from Moravany-Žakovska, Western Slovakia. Geoarchaeology 10 (4), 237-255.

Bridge, J., 2003. Rivers and Floodplains, Forms, Processes and Sedimentary Record. Blackwell, Oxford.

Dittrich, A., 2013. Continuity, change and material memory - Taking a temporal perspective on the Neolithisation in Northeastern Af- 
rica. In: Shirai, N. (Ed.), Neolithisation of Northeastern Africa. SENEPSE 16, 109-120, ex oriente, Berlin.

Dittrich, A., in press a. Between two rivers - early Holocene landscapes on Mograt Island (Sudan). Proceedings of the International Symposium "Desert and the Nile. Late Prehistory of the Nile Basin and the Sahara", 1-4 July 2015, Poznań.

Dittrich, A., in press b. Revolutions of the Middle Nile - the dynamics of a Holocene river scape. Proceedings of the workshop "Revolutions - The Neolithisation of the Mediterranean Basin: The Transition to Food-Producing Economies in North Africa and Southern Europe", 29-31 October 2015, edition Topoi, Berlin.

Dittrich, A., Gessner, K., 2014. Early Holocene landscapes on Mograt Island (Sudan) - perspectives and first results of the Late Prehistoric Survey 2014. Der antike Sudan, MittSAG 25, 127-144.

Dittrich, A., Gessner, K., Neogi, S., Ehlert, M., Nolde, N., 2015. Holocene stratigraphies and sediments on Mograt Island (Sudan) - The second season of the Late Prehistoric Survey 2014/15, Der antike Sudan, MittSAG 26, 123-144.

Durand, N., Monger, H., Canti, M., 2010. Calcium Carbonate Features. In: Stoops, G., Marcelino, V., Mees, F. (Eds), Interpretation of Micromorphological Features of Soils and Regoliths, 149-194, Elsevier, Amsterdam.

Fedoroff, N., Courty, M., Guo, Z., 2010. Palaeosoils and Relict Soils. In: Stoops, G., Marcelino, V., Mees, F. (Eds), Interpretation of Micromorphological Features of Soils and Regoliths, 623-662, Elsevier, Amsterdam, Amsterdam.

Gerrard, J., 1992. Soils Geomorphology. Chapman \& Hall, New York.

Kooistra, L.I., Pulleman, M., 2010. Features Related to Faunal Activity. In: Stoops, G., Marcelino, V., Mees, F. (Eds), Interpretation of Micromorphological Features of Soils and Regoliths, 397-418, Elsevier, Amsterdam.

Kovda, I., Mermut, A., 2010. Vertic Features. In: Stoops, G., Marcelino, V., Mees, F. (Eds), Interpretation of Micromorphological Features of Soils and Regoliths, 109-127, Elsevier, Amsterdam.

Kraus, M., 1999. Paleosols in Clastic Sedimentary Rocks: Their Geologic Applications. Earth Science Reviews 47 (1), 41-70.

Kühn, P., Aguilar, J., Miedema, R., 2010. Textural Pedofeatures and Related Horizons. In: Stoops, G., Marcelino, V., Mees, F. (Eds), Interpretation of Micromorphological Features of Soils and Regoliths, 217-250, Elsevier, Amsterdam.

Lindbo, D., Stolt, M., Vepraskas, M. 2010. Redoximorphic Features. In: Stoops, G., Marcelino, V., Mees, F. (Eds), Interpretation of Micromorphological Features of Soils and Regoliths, 129-147. Elsevier, Amsterdam.
McCarthy, P., Plint, A., 1998. Recognition of Interfluve Sequence Boundaries: Integrating Paleopedology and Sequence Stratigraphy. Geology 26 (5), 387-390.

Mücher, H., Steijn, H., Kwaad, F., 2010. Colluvial and Mass Wasting Deposits. In: Stoops, G., Marcelino, V., Mees, F. (Eds), Interpretation of Micromorphological Features of Soils and Regoliths, 37-48, Elsevier, Amsterdam.

Näser, C., 2006. Die Humboldt University Nubian Expedition 2006 Arbeiten auf Us und Mograt. Der antike Sudan, MittSAG 17, 1-28.

Näser, C., 2008. Die Humboldt University Nubian Expedition 2008 - Arbeiten auf der Insel Mograt. Der antike Sudan, MittSAG 19, $47-52$.

Pachur, H.-J., Altmann, N., 2006. Die Ostsahara im Spätquartär - Ökosystemwandel im größten hyperariden Raum der Erde. Springer, Berlin and Heidelberg.

Pagliai, M., Stoops, G., 2010. Physical and Biological Surface Crusts and Seals. In: Stoops, G., Marcelino, V., Mees, F. (Eds), Interpretation of Micromorphological Features of Soils and Regoliths, 419-440, Elsevier, Amsterdam.

Pal, D., Dasog, G., Vadivelu, S., Ahuja, R., Bhattacharyya, T., 2000. Secondary Calcium Carbonate in Soils of Arid and Semi-Arid Regions of India. In: Lal, R., Kimble, J., Eswaran, H., Stewart, B. (Eds), Global Climate Change and Pedogenic Carbonates, 149185, Lewis Publishers, Boca Raton.

Schaetzl, R., Anderson, S., 2005. Soils: Genesis and Geomorphology. Cambridge University Press, Cambridge.

Sehgal, J., Stoops, G., 1972. Pedogenic Calcite Accumulation in Arid and Semi-Arid Regions of the Indo-Gangetic Alluvial Plain of Erstwhile Punjab (India) - Their Morphology and Origin. Geoderma 8 (1), 59-72.

Simonson, G., Boersma, L., 1972. Soil Micromorphology and Water Table Relations: II. Correlation between Annual Water Table Fluctuations and Profile Features. Soil Science Society of America Journal 36 (4), 649-653.

Stolt, M., Lindbo, D., 2010. Soil Organic Matter. In: Stoops, G., Marcelino, V., Mees, F. (Eds), Interpretation of Micromorphological Features of Soils and Regoliths, 369-390, Elsevier, Amsterdam.

Whiteman, A.J., 1971. The Geology of the Sudan. Clarendon Press, Oxford.

Williams, M.A.J., 2009. Late Pleistocene and Holocene environments in the Nile basin. Global and Planetary Change 69, 1-15.

Yaalon, D., 1983. Climate, Time and Soil Development. In: Wilding, L., Smeck, N., Hall, G. (Eds), Pedogenesis and Soil Taxonomy I: Concepts and Interactions, 223-251, Elsevier, Amsterdam. 